\title{
Repressed Histories
}

\author{
Book Review
}

\section{CHRISTEN CORNELL}

Andrew McGahan

The White Earth

Allen \& Unwin, Sydney 2004

ISBN 1-7414-147-8

RRP \$29.95 (pb)

At first glance, Andrew McGahan's most recent novel, The White Earth, might appear to be about Aboriginal people and culture. It is set on a farm on the Darling Downs during the drafting of Mabo legislation, and is about land rights, Native title and the history of Aboriginal massacres in that region. The White Earth, however, is remarkable precisely for its eschewing of this kind of discussion about Aboriginality, focusing exclusively on the impact of these events and issues upon white Australia rather than their constitution of an Aboriginal 'issue' or 'problem'. Speaking neither for nor about Aboriginal culture or people, the book dwells instead on the question of their place within the white psyche, their inevitable shaping and influence of a white culture that is preoccupied with their denial.

When William's father is killed in a fire, the young boy and his mother are invited to live with his great uncle John McIvor in his decaying colonial mansion on the colossal Kuran Station. An 
expansive remnant of one of the area's first enormous cattle runs, Kuran Station was originally the estate of the White family, a once powerful local dynasty whose supremacy has long since dissolved, and whose descendents have now all moved on. One of the last remaining people to have known the estate in these glory years, and now its proud but aging owner, John McIvor is on the lookout for an heir, somebody he can rely on to share his own conception of the land and defend it from the impending threat of a world gone mad for minority groups, from national parks and Native title.

Like a boy sent on walkabout, William is removed from school for a year in order to have his mettle tried and tested, to be taught and trained by his great uncle in the stories and wisdom of the estate. As the plot progresses, however, John Mclvor's understanding and ownership of the country is shown to be contingent, reliant upon not only temporal colonial orthodoxies, but also the violence of his ancestors, personal vendettas, greed and fear. What begins as a seemingly natural and unquestionable understanding of self and the land gradually becomes prized from its position of authority, as John's daughter Ruth, a lawyer in Native title and repository of family knowledge, arrives with stories incommensurate with those of William's great uncle, and as the land starts to speak for itself.

For more than the first half of The White Earth, all terms, frameworks and assumptions remain limited to what William is taught by his uncle. This is one of a number of the book's 'unreliable narrators', voices that hold together with their own sense of logic and even compassion until an alternative arrives and casts doubts upon its integrity. This particular voice, one that many of us (over a certain age) would be familiar with from school, tells the history of the region exclusive of the knowledge and existence of Aboriginal people. The European explorer Kirchmeyer was 'one of the first people to cross this part of the country'; the black soil plains are bare of trees not because of the Aboriginal practice of burning, but because in drought, the ground can't support their roots; and of course, the arrival of Europeans was the first time the Kuran Plains were adapted, and so claimed, by human use.

John McIvor is at pains to establish that he is not racist and that he respects Aboriginal culture; but he insists that this is gone now, inevitably (if lamentably) dislodged by the agricultural might of the white man. Those who want to recognise Aboriginal conceptions of the land or, even more outlandishly, to argue for the acknowledgement of a continuing Aboriginal presence in Australia are only turning back the clock, trying to remove from farmers what they have earned over generations with bravery, determination and with their own respect and love of the land. One system has supplanted another, a fact proven no more convincingly to John McIvor than by his own deep affinity with his country. As the dubitable means by which he has acquired his property are revealed, however; as we learn of a history of calculated relationships and suspicious bequests; as William becomes audience to tales of life on the plains before white settlement, to descriptions of the law, politics and possibility of Native title, John McIvor's 
spiritual and legal possession of the land begins to seem more tenuous, until eventually, his hold on the whole estate gives way. 'Knowledge, that [is] the issue', thinks William as he is exposed to its new and varying versions. 'Knowledge [is] the essence of ownership.'

In The White Earth knowledge is not only that recorded in the documents and archives of white civilisation, but also that preserved in its oral traditions, in the information passed on from elders that endows special rights upon those who receive it. This is one of the many ways in which the book aligns the mechanisms of white storytelling with those of Indigenous Australians, suggesting the importance of myth to both cultures, and so upsetting their division into categories of modern and pre-modern. By the waterhole, a site of white sacred significance, Uncle John speaks to his great nephew:

That's the sort of thing you have to know about a piece of land, Will, if you're going to own it. You have to be able to know where it fits in. You don't just buy a few square miles and put up a fence and say, This is it. Every stretch of earth has its story. You have to listen and understand what connects it with other stories. Stories that involve the whole country in the end. (106)

Mythology creates ties that are essential, bonds that surpass the legal in justifying moral rights to the country. Again, as John says to William:

We can have connections with the land too, our own kind of magic. This land talks to me. It doesn't care what colour I am, all that matters is that I'm here. And I understand what it says, just as well as anyone before me, black or white. I found this [bora] ring, didn't I? So I deserve respect too.

The difference in the case of white culture, however, is that this mythologising is done in order to establish possession; and with possession comes a fear of dispossession, and so a need to suppress others' stories. Private land must be protected with privacy and secrets must be kept, like those of the bora rings and waterhole on John McIvor's land that still speak of a previous Aboriginal presence. 'Australia-every square inch of it-is our sacred site', insists John McIvor, betraying with his insistence the fact he's now on the defence. These places pulsate with even more meaning than ever today, threatening to open his property to the curiosity of prying outsiders, to speak alternative mythologies of the land.

In this way, throughout the novel, history refuses to remain in the past, but increases in volume and significance the longer it remains repressed. History is interwoven with the present, is lived almost simultaneous with it, balanced in interrelation. Oscillating backwards and forwards across time, the book unfolds the past in order to advance the plot, explaining with every step into memory why events at Kuran Station transpire as they do today.

The consequences of this history's denial are likewise manifest in the present, expressed in the sickness of farms gripped by drought, and in William, who suffers an earache. Intensifying the longer he tries to ignore it, William's wound begins to emit an increasingly foul stink of rotting, making him feel nauseous, confused and aware, even if only viscerally, that 'something [is] 
profoundly wrong'. Burdened with the repressed memories of his ancestors, William's present remains distorted; both the product and the victim of his forefathers' unacknowledged misdeeds, he is unable to experience innocence. In an unwitting performance of this, William spends the second half of the novel parading about in the hat of his great uncle's father, proudly bearing its badge of QMP, not realising the hat was worn during his ancestor's years of service as an officer of the Queensland Mounted Native Police, 'dispersing' or, that is, slaughtering blacks on the Darling Downs. Instead, William thinks it a family heirloom, a symbol of the ties between him and his uncle, of no more than sentimental significance. Wearing the hat, William 'tossed and rolled for hours, reflecting on the day ... hardly aware that his ear had started to ache again'. Not wanting to bother the adults, not even trusting the doctor at hand, William tries to ignore the smell and ache of his ear. He takes drugs to keep the peace, unsure of whether this actually fades the pain. As the novel continues, as ghosts start to speak and as William's overriding feeling of seasickness increases, the question of William's inheritance shifts from one of whether he will prove himself worthy, to one of whether he, ultimately, would even want it.

The land is also, here, conceived of as an actor, a character in the plot with its own motivations, plans and agents. It speaks via the seasons and spirits, voices what it has seen and exacts punishment upon humans for offences that go unchecked. It reflects the behaviour and the psyche of the people, withholding water when they keep secrets, combusting into flames when they are enraged. It is the country that finally exposes the truth upon which the plot is hinged, drying up the creeks to reveal the bones that explain the root of John McIvor's lust to possess the land. Even John McIvor himself believes in the land's own agency, harbouring, after watching his father-in-law burn to death, a 'secret belief ... that, in his hour of greatest need, the hills of his station had ignited by themselves that night, and so devoured his enemy'.

This respect of the land as an entity, capable of expressing moral outrage, is just one of the many ways McGahan's novel reminds the reader of traditional Indigenous conceptions of the world, and yet thankfully, and refreshingly, suggests ways in which these modes of storytelling might have their effects on, or relevance to, whites. A series of themes that might usually, and even stereotypically, be seen to relate to Aboriginal people are, in The White Earth, the concerns of white Australians: spiritual connections with the land (as opposed to the simply rational, economic or scientific); the significance of myth and oral traditions (rather than only archives and official, 'capital H' history); the sense of a loss of culture, of dying traditions and knowledge (felt in this case, by neo-nationalist pastoralists); and the tragedy of Aboriginal massacres (experienced here, by its traumatising of white descendents). An Aboriginal presence is felt consistently throughout the book-in the name of Kuran station, in the faces just visible in a dark corner of a painting that hangs in the study and, most conspicuously, in John Mclvor's fear of Native title-but this is always expressed as something within white culture, its power to define this culture increasing the longer it goes unspoken. 
There is not one Aboriginal character in The White Earth, and the title speaks explicitly of the book's concerns. Even the arguments we are given for Native title are not put to us by Aboriginal people, but by a white woman versed in white law, using them to get back at her father. It would be possible, even, to argue that The White Earth is unsuitable for consideration alongside literature on Aboriginality in Australia, except that the book is extraordinary in this very regard, worth mentioning exactly for its means and point of departure from more traditional approaches to writing about Aboriginal culture. It articulates a respect in all its does not say, not only leaving room for Aboriginal voices to fill for themselves but, more importantly, exploring some of the results of the two cultures' engagement. Writing these stories as intrinsic to white culture and consciousness, McGahan presents them as necessary for white Australians' understandings of themselves. It is for this reason that the book has already become referred to as 'a white man's dreaming', a fable-like, spiritual tale to help explain the land and history that contemporary white Australians have inherited.

As in his previous works of fiction, McGahan's awareness of his deployment of literary devices, of traditional fictional techniques prevents The White Earth from reading as a trite or naive repetition of these familiar conventions. He builds suspense with locked doors and prohibitions, punctures it with timed anti-climaxes, lays and never wastes his references as characters arrive to take up their narrative function. Themes of fire, drought and flood are carefully developed and played out, premonitions are duly fulfilled, and the end of the book is even gripped by a classic sense of welling, of secrets' impending exposure by the elements and a correcting of moral imbalance. Tricks so archetypal they risk seeming clichéd, predictable or contrived are pulled off due to McGahan's self-consciousness of the conceits of his genre, along with the dexterity and maturity with which he performs them. The White Earth could be compared to a Patrick White in its scope, depth and content, utterly convincing at a time in which this type of classic, modern novel is in certain literary circles becoming debatable as anachronistic.

The White Earth is McGahan's most ambitious book yet: possible only, perhaps, after his having written through the more personal stories of his own life and subjectivity; successful especially, perhaps, due to his focus on the stories of his own broader culture. Taking the potential polemic of black-white relations for his subject, probing at fundamental questions of morality, McGahan has managed to write a book that doesn't preach, but slowly prizes one belief system loose with another, exposing their contradictions and consistencies, and their contingency upon systems of power.

Christen Cornell is a writer and researcher based in Sydney.<christen.cornell@uts.edu.au> 